\title{
Decadal variability in growth of the Caribbean spiny lobster Panulirus argus (Decapoda: Paniluridae) in Cuban waters
}

\author{
Maria Estela de León ${ }^{1 *}$, Juana López Martínez², Daniel Lluch Cota ${ }^{3}$, Sergio Hernández Vázquez ${ }^{3}$ \\ \& Rafael Puga ${ }^{1}$ \\ 1 Centro de Investigaciones Pesqueras. 5a Avenida y Calle 246, Barlovento, Sta. Fe, Playa. Apartado Postal 19100. \\ Ciudad de La Habana. Cuba. mestela@ cip.telemar.cu \\ 2 Centro de Investigaciones Biológicas del Noroeste, S.C. Unidad Guaymas. Apartado Postal 349, Guaymas 85465, \\ Sonora, México. \\ 3 Centro de Investigaciones Biológicas del Noroeste, S.C. Apartado Postal 128. La Paz, B.C.S., 23000, México.
}

Received 15-IV-2005. Corrected 12-VII-2005. Accepted 20-VII-2005.

\begin{abstract}
Annual von Bertalanffy growth parameters of the Caribbean spiny lobster (Panulirus argus) in Cuban waters were estimated from a long term study (40 years) by length-based methods ELEFAN and the new version of SLCA. Data of around 800000 lobsters (with carapace length ranging 14 to $199 \mathrm{~mm}$ ) were randomly sampled in artificial shelters (a non selective fishing gear very common in the lobster fishery), through the field monitory program established for this species since 1963 in 14 localities of southwestern Cuban shelf. The software ELEFAN showed problems to converge in an optimal combination of the instantaneous growth coefficient $(K 2$ and the asymptotic length $\left(L_{\infty}\right)$ of the von Bertalanffy equation, whereas the new SLCA software produced value estimates of $K$ between 0.20 and 0.27 year $^{-1}$ and values of $L_{\infty}$ between 177 and $190 \mathrm{~mm}$ carapace length, all within the range reported in the literature. The standardized anomalies of both parameters showed the presence of cycles along the analyzed time series. Decadal variability in growth parameters was revealed through the spectral analysis indicating cycles of 16 and 20 years for $K$ and of 16 years for $L_{\infty}$. The incidence of some factors such as biomass and temperature that modulate growth in this crustacean was explored, using a nonlinear multiple regression model. These combined factors explained $33 \%$ and $69 \%$ of the variability of $K$ and $L_{\infty}$ respectively. The growth coefficient appeared to be maximum with annual mean sea surface temperature of $28.1^{\circ}$ $\mathrm{C}$ and the largest $L_{\infty}$ is reached at a annual men biomass level of 23000 t. These results should be the basis to understand the Cuban lobster population dynamics. Rev. Biol. Trop. 53(3-4): 475-486. Epub 2005 Oct 3.
\end{abstract}

Key words: Growth parameters, decadal variability, Panulirus argus, Cuba.

The Caribbean spiny lobster, Panulirus argus (Latreille, 1804), is widely distributed throughout the tropical and subtropical waters of the Western Central Atlantic Ocean, ranging from North Carolina, U.S.A., to Sao Paulo in Brazil, and extending through the Bahamas, Bermudas and the Greater and Lesser Antilles. It is usually recorded from shallow waters, but may occur down to about $90 \mathrm{~m}$ (Tavares 2002). The fishery of this crustacean has significant importance for the countries of the region. The attractiveness of this low cost and high revenue activity has lead the resource to be in a fully to over-exploited conditions along its entire distribution range (Puga and de León 2003).

Cuba, one of the largest producers of P. argus, carry out their fisheries all around the country, but this activity is particularly important in the Southwest shelf, commonly named Gulf of Batabano. This area produce $60 \%$ of the total national catch and is characterized by shallow-water rocky habitats, mangroves and seagrass beds (Páez and Revilla 1991), where the Caribbean spiny lobster found the adequate habitat to develop the benthic stages of its life history. The most important features on the biology, fisheries and management 
of the species in Cuban waters are examined by Baisre and Cruz (1994).

Since 1963, a biological sampling program in Cuban fishing grounds provides monthly information on size, sex-ratios, reproductive activity and molting frequency of $P$. argus stock. Fishery information is also available through a detailed data-collection system. Both sources are systematically analyzed at the Fisheries Research Centre, which gives off the recommendations to be annually included in the management plan for the sustainable use of the stock (Puga and de León 2003).

Age of crustaceans cannot be directly determined due to the lack of permanent hard body parts, so most growth studies on Caribbean spiny lobster have relied on length-frequency analysis. More than 20 estimates of $P$. argus growth parameters, adjusting the von Bertalanffy growth function (VBGF), have been obtained in different areas of the Western Central Atlantic in several times. The obtained parameters are listed in Arce and de León (2001), including those from Cuba during the 60's (Buesa 1972), the 70's (Cruz et al. 1981), the 80's (Baez et al. 1991, de León et al. 1993) and the 90’s (de León et al. 1995). Only a few studies have explored other functions to describe growth in Caribbean spiny lobster (Arce et al. 1991, Zetina and Rios 1999).

Taking into account the long- term series available of biological information (1963-2002), this study was conducted to obtain annual growth parameter of $P$. argus in Cuban waters using a single methodology to adjust VBGF, to determinate periods of particularly fast or slow growth and the existence of some kind of interannual to decadal patterns in their behavior. The incidence of some factors that modulate growth in this valuable crustacean is explored.

\section{MATERIALS AND METHODS}

Data sources: The biological data collection system on $P$. argus was designed to obtain random samples of lobsters from artificial shelters, a non-selective fishing gear very common in the Cuban lobster fishery. Details of the sampling methodology are described by Cruz (2002). Monthly field samples in the Gulf of Batabano from 1963-2002 were carried out in 14 localities. The information of about 800 000 lobsters has been processed at the Centro de Investigaciones Pesqueras (C.I.P.) between 1963-2002 to generate monthly frequency distributions of carapace length $(C L)$,considering $5 \mathrm{~mm}$ class intervals. The Table 1 shows the number of lobsters and the length range sampled by year.

While local conditions (temperature, food, etc) may affect the precise course of the growth, data of monthly mean sea surface temperature (SST) in the Gulf of Batabanó (22.5 $\mathrm{N}$ and $82.5^{\circ} \mathrm{W}$ ) was average over the year for the period 1963 - 2002 (Table 2) to test the relevance of temperature over growth parameters. The SST data series were kindly provided by the Centro de Investigaciones Biológicas del Noroeste, México, originally obtained from ftp://ftp.cdc.noaa.gov and based on optimal interpolation sea surface temperature according to Reynolds et al. (2002).

To explore the relationship between $K$ and $L_{\infty}$ with lobster biomass, annual mean lobster biomass $(B)$ for the analyzed period (Table 2) was gently contributed by Puga as an extension of his previous paper (Puga et al. 2005) based on a sequential population analysis (SPA) with the ADAPT framework.

Growth parameters estimation: Despite of being criticized (Knight 1968, Roff 1980), the simple VBGF continues being the most commonly used growth model in fishery science, because of its easy way to be incorporated in many stock assessment techniques:

$$
L_{t}=L_{\infty}\left\{1-\exp \left[-K\left(t-t_{0}\right)\right]\right\}
$$

Where:

$L_{\infty}$ is the asymptotic average maximum body size. $K$ is the growth coefficient which determines how quickly $L_{\infty}$ is attained.

$t_{0}$ is the hypothetical age when $L_{t}$ is cero. 
TABLE 1

Number of lobsters and the carapace length range sampled by year (1963-2002)

\begin{tabular}{|c|c|c|c|}
\hline Year & $\mathrm{N}$ & $\begin{array}{c}\text { CL min. } \\
(\mathrm{mm})\end{array}$ & $\begin{array}{c}\text { CL max. } \\
(\mathrm{mm})\end{array}$ \\
\hline 1963 & 13919 & 31 & 142 \\
\hline 1964 & 20220 & 27 & 147 \\
\hline 1965 & 35543 & 26 & 149 \\
\hline 1966 & 10223 & 45 & 153 \\
\hline 1967 & 14468 & 31 & 137 \\
\hline 1968 & 9999 & 46 & 142 \\
\hline 1969 & 10701 & 35 & 152 \\
\hline 1970 & 11040 & 45 & 160 \\
\hline 1971 & 16357 & 37 & 154 \\
\hline 1972 & 16778 & 37 & 159 \\
\hline 1973 & 19675 & 41 & 148 \\
\hline 1974 & 21589 & 35 & 158 \\
\hline 1975 & 31405 & 41 & 173 \\
\hline 1976 & 37271 & 46 & 162 \\
\hline 1977 & 30559 & 45 & 150 \\
\hline 1978 & 28874 & 47 & 158 \\
\hline 1979 & 12457 & 35 & 149 \\
\hline 1980 & 13376 & 50 & 153 \\
\hline 1981 & 6408 & 46 & 158 \\
\hline 1982 & 8078 & 45 & 150 \\
\hline 1983 & 17974 & 28 & 157 \\
\hline 1984 & 10734 & 27 & 160 \\
\hline 1985 & 11484 & 30 & 163 \\
\hline 1986 & 16814 & 26 & 181 \\
\hline 1987 & 21574 & 25 & 173 \\
\hline 1988 & 19122 & 25 & 186 \\
\hline 1989 & 26814 & 23 & 192 \\
\hline 1990 & 26436 & 29 & 167 \\
\hline 1991 & 62984 & 16 & 198 \\
\hline 1992 & 48992 & 30 & 199 \\
\hline 1993 & 53439 & 14 & 199 \\
\hline 1994 & 11188 & 26 & 179 \\
\hline 1995 & 14628 & 24 & 192 \\
\hline 1996 & 14086 & 47 & 167 \\
\hline 1997 & 12420 & 44 & 169 \\
\hline 1998 & 13340 & 40 & 168 \\
\hline 1999 & 15597 & 41 & 165 \\
\hline 2000 & 10553 & 45 & 166 \\
\hline 2001 & 8576 & 43 & 159 \\
\hline 2002 & 12089 & 45 & 163 \\
\hline
\end{tabular}

Other models concerning growth have been developed; this is the case of molt-based model which has apparently a more realistic fit to represent growth in lobster (Caddy 1977), however, it is more rigorous regarding
TABLE 2

Annual sea surface temperature (SST) and annual mean lobster biomass (B) data for the Gulf of Batabanó (1963-2002)

\begin{tabular}{|c|c|c|}
\hline Year & $\begin{array}{c}\text { Annual } \\
\text { mean SST } \\
\left({ }^{\circ} \mathrm{C}\right)\end{array}$ & $\begin{array}{c}\text { Annual } \\
\text { mean B } \\
\text { (t) }\end{array}$ \\
\hline 1963 & 28.17 & 15180 \\
\hline 1964 & 28.10 & 15633 \\
\hline 1965 & 28.03 & 16956 \\
\hline 1966 & 28.12 & 16207 \\
\hline 1967 & 28.06 & 15880 \\
\hline 1968 & 28.09 & 16323 \\
\hline 1969 & 28.02 & 16822 \\
\hline 1970 & 27.86 & 16002 \\
\hline 1971 & 27.90 & 16829 \\
\hline 1972 & 27.91 & 17387 \\
\hline 1973 & 27.97 & 18647 \\
\hline 1974 & 27.81 & 21137 \\
\hline 1975 & 27.84 & 20649 \\
\hline 1976 & 27.70 & 20070 \\
\hline 1977 & 27.92 & 18389 \\
\hline 1978 & 28.05 & 20949 \\
\hline 1979 & 27.93 & 20579 \\
\hline 1980 & 28.06 & 20287 \\
\hline 1981 & 27.98 & 20801 \\
\hline 1982 & 28.15 & 21224 \\
\hline 1983 & 27.86 & 21415 \\
\hline 1984 & 27.78 & 23517 \\
\hline 1985 & 28.01 & 24482 \\
\hline 1986 & 28.05 & 23909 \\
\hline 1987 & 28.01 & 24866 \\
\hline 1988 & 27.88 & 24893 \\
\hline 1989 & 27.83 & 24410 \\
\hline 1990 & 28.02 & 23238 \\
\hline 1991 & 28.03 & 25240 \\
\hline 1992 & 27.88 & 24624 \\
\hline 1993 & 27.93 & 23770 \\
\hline 1994 & 28.06 & 23452 \\
\hline 1995 & 28.15 & 21788 \\
\hline 1996 & 27.94 & 20083 \\
\hline 1997 & 28.01 & 18892 \\
\hline 1998 & 28.06 & 19097 \\
\hline 1999 & 27.96 & 18663 \\
\hline 2000 & 27.98 & 17369 \\
\hline 2001 & 28.07 & 18520 \\
\hline 2002 & 28.02 & 19918 \\
\hline
\end{tabular}

data-requirements such as high expensive tagging programs and/or lab studies.

Taking into account the nature of the information available, the three-parameter VBGF was fitted to length-frequency data by two 
indirect methods to estimate growth parameters: Electronic Length Frequency Analysis, ELEFAN 1 (Pauly and David 1981) and New Shepherd's Length Composition Analysis, NSLCA (Shepherd 1987, Pauly and ArreguínSánchez 1995). Both routines are available in FAO ICLARM stock assessment tools, FISAT, in its Windows version (Gayanilo et al. 1996).

The ELEFAN routine in FISAT suit of programs fits VBGF by a non-parametric method where an optimum curve, which cross through the most number of modes, is selected based on a goodness of fit value.

The NSLCA method is similar to ELEFAN, maximizing a non-parametric scoring function. It fits a circular function to the overall lengthfrequency distribution of each sample, and in the process, computes a total score function for a set of samples. At the maximum score function, the growth curve with the testing $L_{\infty}$ and $K$ values predicts the modal lengths closer to the observed values.

Annual values of $t_{0}$ were obtained by the inverse VBGF: $t_{0}=t+1 / K * \ln \left[\left(1-L_{t}\right) / L_{\infty}\right]$, considering the analysis proposed by Cruz et al. (1991) in puerulus collectors in Cuban waters, where puerulus stage of $P$. argus returns to the SW Cuban shelf seven months after larval release, attaining a length of $5.78 \mathrm{~mm}$ of carapace length $(C L)$.

The values of $L_{\infty}$ expressed in $C L$ were transformed into total lengths (TL) according the relationship published by Cruz (2002) (TL $=2.5402 * C L+36.3535)$ to calculate the overall growth performance index $\Phi^{\prime}$ (Pauly and Munro 1984): $\Phi^{\prime}=\log _{10} K+2 \log _{10} L_{\infty}$.

The overall growth performance indexes $\Phi^{\prime}$ were also calculated with $L_{\infty}$ and $K$ values listed in Arce and de Leon (2001) concerning growth studies of Caribbean spiny lobster in Western Central Atlantic. The index $\Phi^{\prime}$ were used as a tool to examine differences among the present annual estimates as well as with others $P$. argus growth parameters in other areas and/or periods.
Time series analysis of growth parameters: The presence of fluctuations and patterns in the annual growth parameters were examined along the 40 year series. A preliminary searching was done through the standard anomalies (SA) behavior around the mean values of $K$, $L_{\infty}$ and $\Phi$ ' for the analyzed period: $S A=\left(X_{i}\right.$ $\left.-X_{m}\right) / S$, where $X_{i}$ is the value of the parameter in the year $i, X_{m}$ is the mean value of the parameter for the considered period and $S$ is the standard deviation. Notwithstanding the close statistical relation between $K$ and $L_{\infty}$ as a result of metabolism and growth across species (Jensen 1997), the average maximum size always will be strongly sensitive on the nature of the length range sampled available (Gulland and Rosenberg 1992), then the decision was focused to investigate the temporal patterns on the time series of $K$ and $L_{\infty}$ instead off explore $\Phi^{\prime}$ patterns directly.

Rhythmic cycles in the annual data of both time series were explored using autocorrelation function. Dominant periodicities were inspected by single spectrum (Fourier) analysis to decompose each series into the energy spectra that shows the concentration of energy or variance under the curve, using a Hamming filter to smooth the periodogram value. All time-series analyses were performed using the computer program Statistica 6.0 (StatSoft 2001).

Relation with temperature and biomass: Present knowledge of the relationship between $P$. argus growth parameters $\left(K\right.$ and $\left.L_{\infty}\right)$ and environmental variables is not sufficient to know a priori their correct form. For that reason, it was applied a nonlinear multiple regression model (or generalized additive model) using Alternating Conditional Expectations algorithm, ACE (Briedman and Friedman 1985) to explore the relationships between the response $\left(K\right.$ and $L_{\infty}$ ) and the predictor variables (SST and $B)$. This methodology was successfully applied to analyze the relation between recruitment and climatic factors in pelagic stocks of Californian 

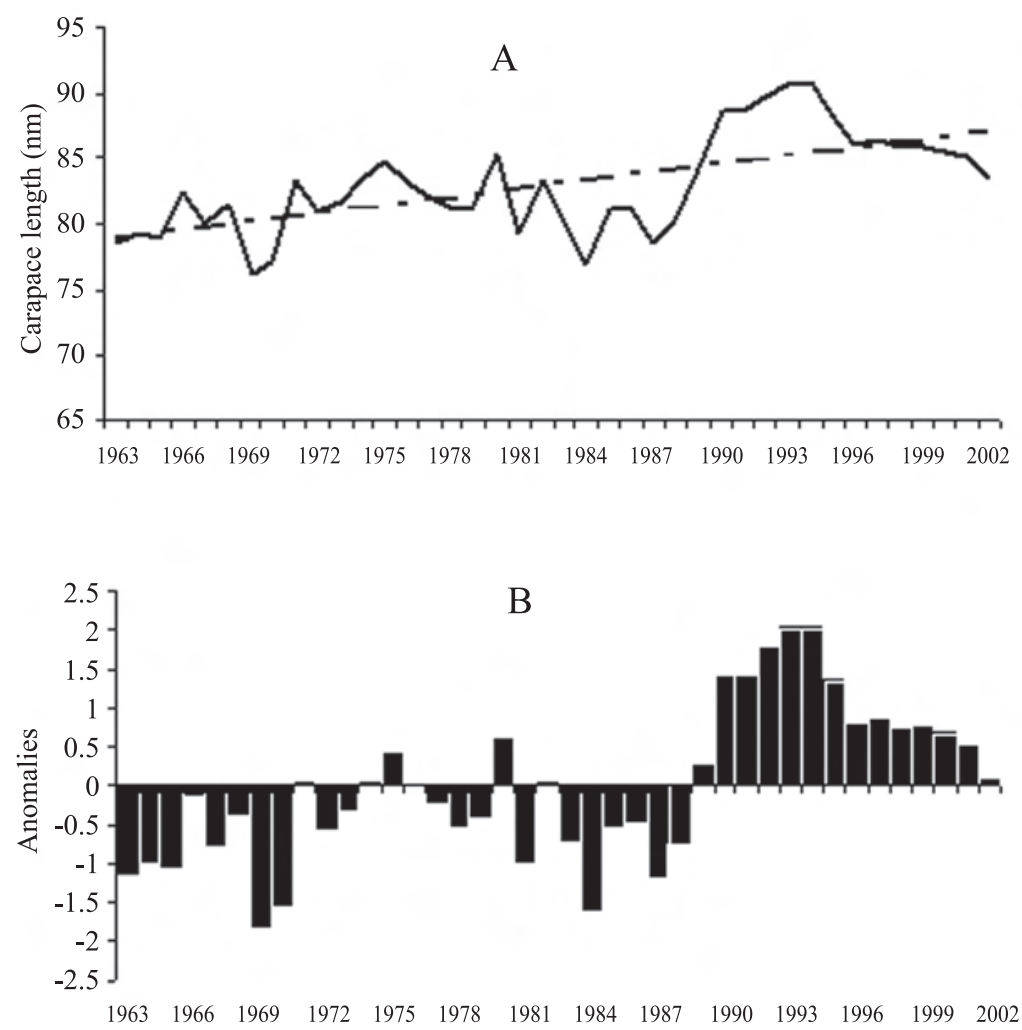

Fig. 1. (A) Annual mean carapace length (CL) and its tendency along the time series. (B) Standardize anomalies of CL.

anchovy (Cury et al. 1995) to obtain an "optimal environmental window".

\section{RESULTS}

Lobster sizes sampled through the four decades has a mean $C L$ of $83.02 \mathrm{~mm}$ and a minimum and maximum $C L$ of 14 and $199 \mathrm{~mm}$ respectively. An evidence of a positive tendency of mean $C L$ is observed along the time series $(y=0.22092+78.737$, Fig. 1a), reaching the highest values during the 1990's. Obvious differences are observed between the average lengths of each year. Moreover, at first glance the standardize anomalies of average $C L$ series (Fig. 1b) reveals the possible presence of periods: two with values generally below the mean (1963-1970 and 1980-1988), one around the mean (1971-1979) and the last (1990-2002), with values greater than the general average $C L$.

Annual growth parameters by ELEFAN routine does not converge in an optimal estimation in the $25 \%$ of the years analyzed. The rest of the years show a tendency to overestimate $\mathrm{L}_{\infty}$, in the $50 \%$ of the cases, with values very far from maximum $C L$ reported for the species, $225 \mathrm{~mm} C L$ in SE Cuba (de León et al. 1995) and in the Mujeres Island, Mexico (González-Cano 1991).

The results obtained with NSLCA routine are better, due to a good convergence of growth parameter in all cases. The $L_{\infty}$ values obtained by NSLCA vary between 170 and $199.1 \mathrm{~mm}$ $C L$ and parameter $K$ fluctuates from 0.20 to 0.27 year $^{-1}$. Average values for $L_{\infty}$ and $K$ were $183.6 \mathrm{~mm} C L$ and 0.2405 year $^{-1}$ respectively.

The combination of annual growth parameters provided indexes $\Phi^{\prime}$ oscillating from 
2.71 and 2.87 with an average of 2.78. In other localities and/or periods, index $\Phi^{\prime}$ ranged from 2.54 and 3.18 and the average value is 2.79 (papers cited by Arce and de León 2001). A summary of present results of annual estimates for $L_{\infty}$ and $K$ as well as $t_{0}$ and $\Phi^{\prime}$ parameters calculated are presented in Table 3.

Since there is much interannual variability in $K$ and $L_{\infty}$ time series, there are significant features exposed in the plots of standardized anomalies of $K$ (Fig. 2a) and $L_{\infty}$ (Fig. 2b) along the 40 years analyzed. Both parameters denote cyclic patterns, although it is more evident in the case of $K$, presenting well defined periods of low and high values, whereas $L_{\infty}$ also seems to have incorporated some positive trend.

The autocorrelation function indicated cycling around 15 years for $L_{\infty}$ and 18 years for $K$.

To carry out time series analysis, previously both series were transformed by tapering at 10\% to reduce linkage in the periodogram and also the respectively mean and tendency ( $K$ : mean $=0.2405$, tendency $=0 ; L_{\infty}$ : mean $=183.6$, tendency $=\mathrm{x}-[-9.074+0.4426 * \mathrm{t}])$ were removed. Spectrum (Fourier) analysis of parameter $K$ series indicated the presence of low-frequency patterns, with significant cycles of 16 and 20 years $(\alpha=0.05)$ (Fig. 3a). Similar results were observed in the spectrum of $L_{\infty}$ series, but the variance was only significantly concentrated in the cycle of 16 years (Fig. 3b).

The relationships between $K$ and $L_{\infty}$ as response factors, with annual means $S S T$ and $B$ as predictors, were explored by plotting the raw data (Fig. 4). No significant relationships between $K$ with annual mean SST (Fig. 4a) and with $B$ (Fig. 4b) were observed, but a positive trend is observed in the first case and a negative in the second one. Asymptotic length and annual mean SST (Fig. 4c) also show no significant relation, however, it seems to have a positive correlation between $L_{\infty}$ with annual mean $B$ (Fig. 4d).

Using the ACE algorithm, the shape of the optimal empirical transformation of the predictor variables from this model are presented in Fig. 5, corresponding $5 \mathrm{a}$ and $5 \mathrm{~b}$ to response

TABLE 3

Annual growth parameters estimated by new SLCA and the growth performance indexes (1963-2002)

$\begin{array}{cccccccccc}\text { Year } & \begin{array}{c}\mathrm{L}_{\infty} \\ \text { mm CL }\end{array} & \begin{array}{c}\mathrm{K} \\ \text { year }^{-1}\end{array} & \begin{array}{c}\mathrm{t}_{0} \\ \text { year }\end{array} & \Phi & & \text { Year } & \begin{array}{c}\mathrm{L}_{\infty} \\ \mathrm{mm} \mathrm{CL}\end{array} & \begin{array}{c}\mathrm{K}^{-1} \\ \text { year }^{-1}\end{array} & \begin{array}{c}\mathrm{t}_{0} \\ \text { year }\end{array} \\ 1963 & 177.5 & 0.24 & 0.44 & 2.76 & 1983 & 176.0 & 0.26 & 0.45 & 2.78 \\ 1964 & 175.0 & 0.22 & 0.43 & 2.71 & 1984 & 184.0 & 0.25 & 0.45 & 2.80 \\ 1965 & 177.4 & 0.27 & 0.46 & 2.81 & 1985 & 183.0 & 0.25 & 0.45 & 2.80 \\ 1966 & 170.0 & 0.27 & 0.45 & 2.77 & 1986 & 190.4 & 0.25 & 0.46 & 2.83 \\ 1967 & 170.2 & 0.27 & 0.45 & 2.77 & 1987 & 186.0 & 0.23 & 0.44 & 2.77 \\ 1968 & 170.5 & 0.27 & 0.45 & 2.77 & 1988 & 189.7 & 0.23 & 0.45 & 2.79 \\ 1969 & 171.0 & 0.26 & 0.45 & 2.76 & 1989 & 194.4 & 0.22 & 0.44 & 2.79 \\ 1970 & 170.6 & 0.24 & 0.44 & 2.72 & 1990 & 196.8 & 0.22 & 0.44 & 2.80 \\ 1971 & 182.5 & 0.21 & 0.43 & 2.72 & 1991 & 185.5 & 0.22 & 0.44 & 2.75 \\ 1972 & 181.4 & 0.21 & 0.43 & 2.72 & 1992 & 195.5 & 0.2 & 0.43 & 2.75 \\ 1973 & 181.6 & 0.21 & 0.43 & 2.72 & 1993 & 196.1 & 0.22 & 0.44 & 2.80 \\ 1974 & 182.5 & 0.21 & 0.43 & 2.72 & 1994 & 194.6 & 0.23 & 0.45 & 2.81 \\ 1975 & 189.0 & 0.22 & 0.44 & 2.77 & 1995 & 192.6 & 0.25 & 0.46 & 2.84 \\ 1976 & 180.0 & 0.23 & 0.44 & 2.75 & 1996 & 180.0 & 0.24 & 0.44 & 2.77 \\ 1977 & 188.0 & 0.25 & 0.46 & 2.82 & 1997 & 180.1 & 0.24 & 0.44 & 2.77 \\ 1978 & 180.3 & 0.24 & 0.44 & 2.77 & 1998 & 179.6 & 0.24 & 0.44 & 2.77 \\ 1979 & 187.0 & 0.25 & 0.45 & 2.82 & 1999 & 199.1 & 0.25 & 0.46 & 2.87 \\ 1980 & 182.2 & 0.25 & 0.45 & 2.79 & 2000 & 190.1 & 0.27 & 0.47 & 2.86 \\ 1981 & 183.5 & 0.25 & 0.45 & 2.80 & 2001 & 180.0 & 0.26 & 0.45 & 2.80 \\ 1982 & 179.0 & 0.25 & 0.45 & 2.78 & 2002 & 189.4 & 0.27 & 0.47 & 2.86\end{array}$



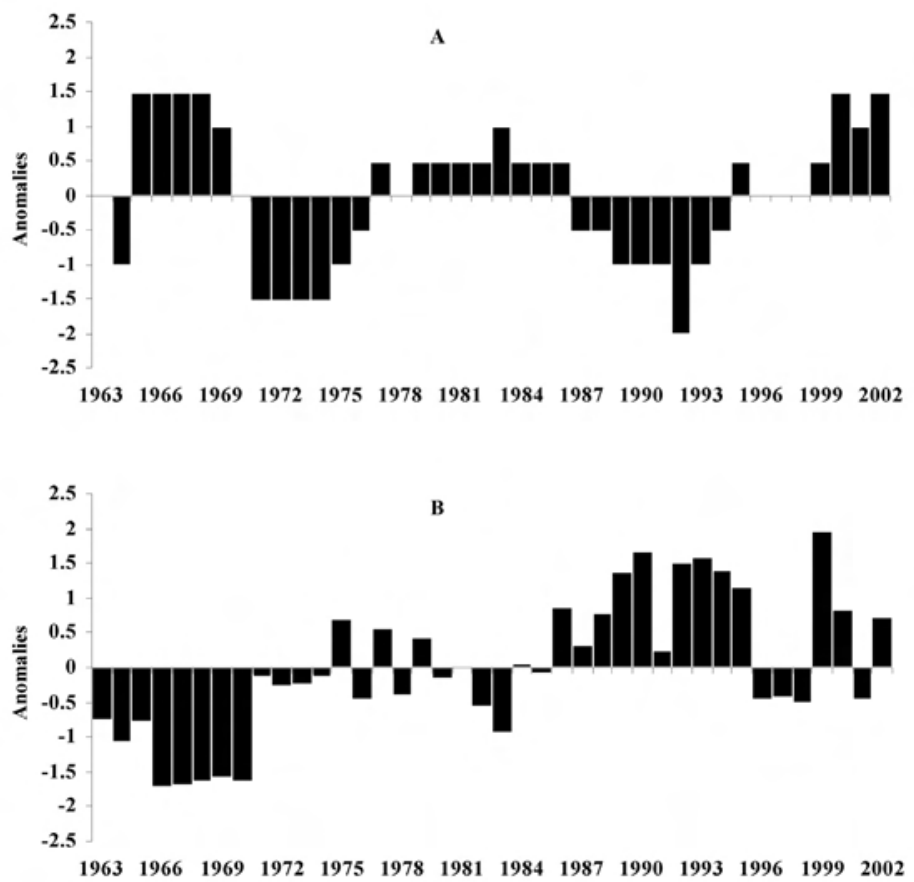

Fig. 2. Standardize anomalies of (A) the instantaneous growth parameter and (B) the asymptotic length along the 40 years studied.
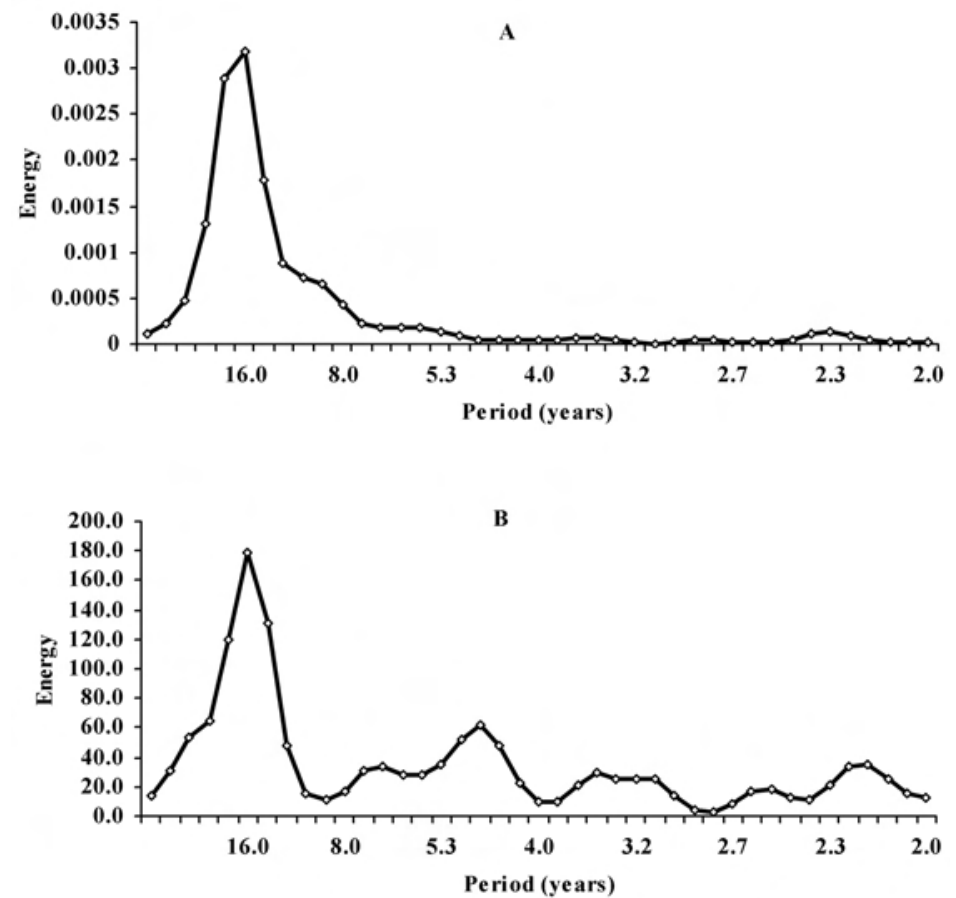

Fig. 3. Spectral analysis of (A) the instantaneous growth parameter with significant cycles of 16 and 20 years and (B) the asymptotic length denoting the variance concentrated in the cycle of years. 
A
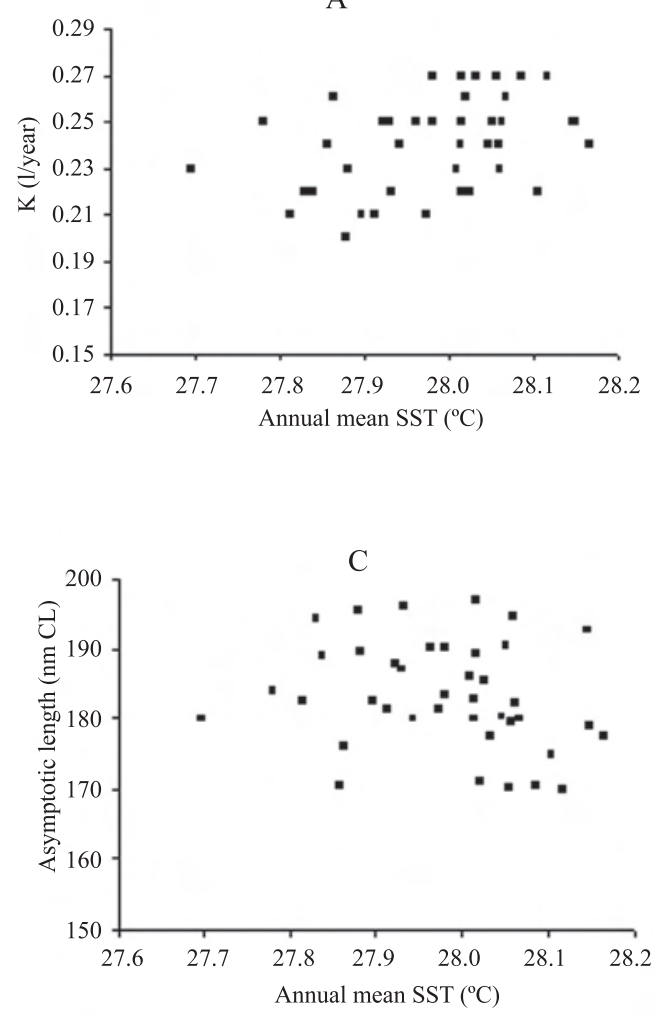

B

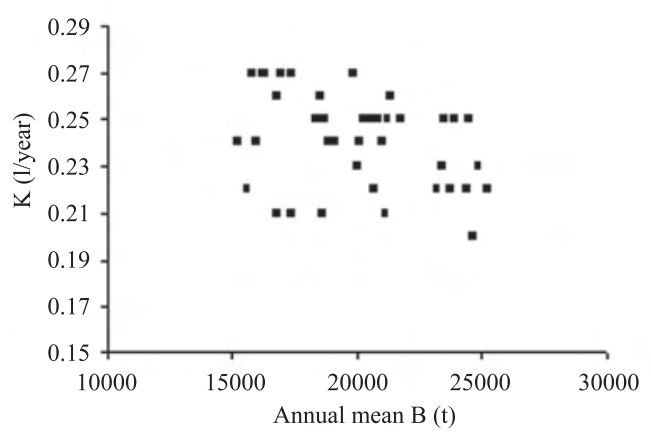

D

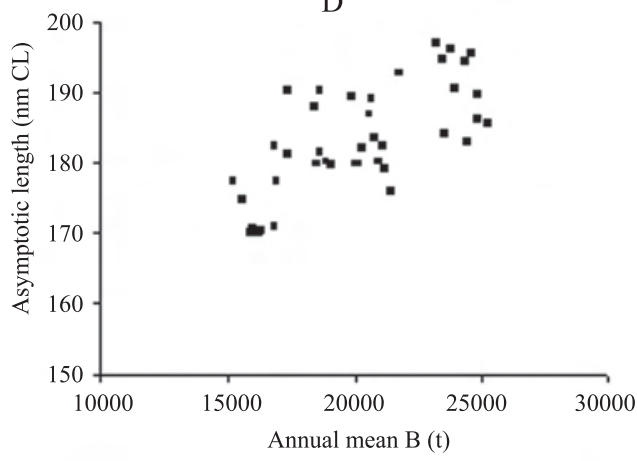

Fig. 4. Plotting raw data of the (A) Annual mean SST $\left({ }^{\circ} \mathrm{C}\right)$ and $(\mathrm{B})$ annual mean biomass (t) versus annual instataneous growth parameter-K. (year-1 ${ }^{-1}$ as dependant variable, and the corresponding transformation of (C) annual mean SST and (D) annual mean biomass with the asymptotic length parameter- $L_{\infty}(\mathrm{mm} \mathrm{CL})$ as response variable.

variable $K$ and $5 \mathrm{c}$ and $5 \mathrm{~b}$ with response variable $L_{\infty}$. Predictor variables explain the $33 \%$ of the variability of $K$ and the $69 \%$ of $L_{\infty}$. However, when both predictors are considered separately in the analysis for each response, the temperature is responsible of the $22 \%$ of the variability of $K$ and annual mean $B$ explain the $61 \%$ of variance of $L_{\infty}$. Growth coefficient looks like to be maximum with annual mean SST of $28.1{ }^{\circ} \mathrm{C}$, and the largest $L_{\infty}$ are reached with levels of annual mean $B$ of $23000 \mathrm{t}$.

\section{DISCUSSION}

Many studies focus on growth estimates have been made for $P$. argus in the Western Central Atlantic, but growth patterns seem to vary markedly between localities probably due to differences in environmental conditions, length composition of the lobsters examined and the method used to estimate growth parameters. It is important to highlight the differences between present results and those obtained by Ivo and Pereira (1996) through ELEFAN routine in Brazilian waters $\left(L_{\infty}=257 \mathrm{~mm} \mathrm{CL}\right.$; $K=0.32$ year $\left.^{-1} ; \Phi^{\prime}=3.18\right)$, by Arce (1990) with SLCA and data of Yucatan Bank in Mexico $\left(L_{\infty}\right.$ $=142 \mathrm{~mm} \mathrm{CL} ; K=0.22$ year $\left.^{-1} ; \Phi^{\prime}=2.54\right)$, by Buesa (1972) with data from the 60's of SW Cuban shelf using Bhattacharya $\left(L_{\infty}=174 \mathrm{~mm}\right.$ $C L ; K=0.16$ year $^{-1} ; \Phi^{\prime}=2.56$ ) and those from Baez et al. (1991) through ELEFAN routine based on data from the 80's in the last mentioned area $\left(L_{\infty}=228 \mathrm{~mm} \mathrm{CL} ; K=0.30\right.$ year $^{-1}$; $\left.\Phi^{\prime}=3.06\right)$.

The results provide evidence of a decadal pattern in the growth of spiny lobster. Decadal cycles in the growth and recruitment have been 

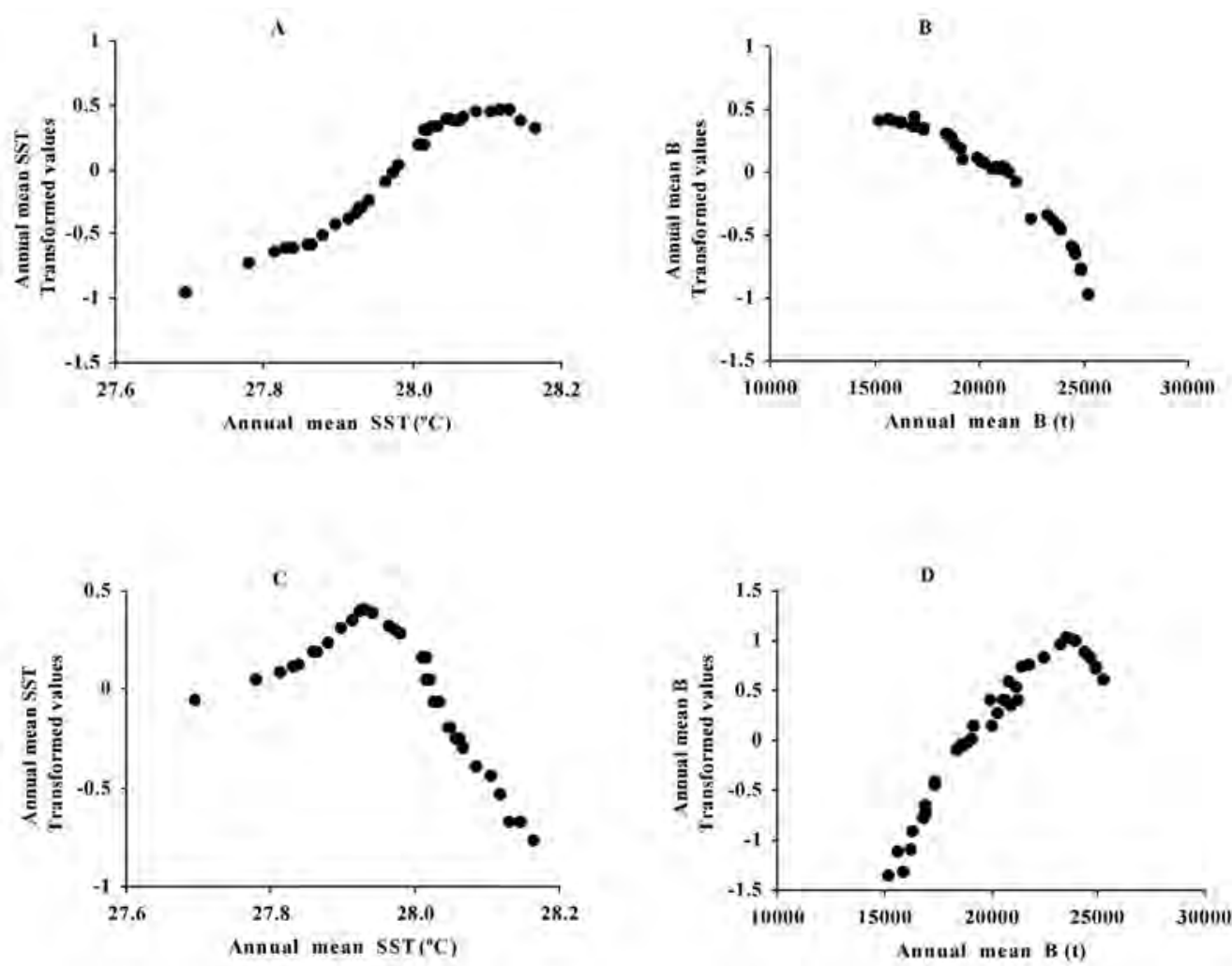

Fig. 5. Optimal empirical transformations from the ACE algorithm, period 1963-2002, of (A) annual mean SST and (B) annual mean biomass using the instantaneous growth parameter- $K$. (year $\left.{ }^{-1}\right)$ as dependant variable, and the corresponding transformation of (C) annual mean SST and (D) annual mean biomass with the asymptotic length parameter- $L_{\infty}(\mathrm{mm} C L)$ as response variable.

documented for halibut in the Pacific (Clark et al. 1999), but no details of this kind of cycles has been found in literature for a tropical organism such as the Caribbean spiny lobster, perhaps due to a lack of long-term biological studies. Acosta et al. (1997) determined temporal patterns in $P$. argus puerulus recruitment in Florida Keys identifying weekly annual patterns in the supply of postlarvae. They also observed an interannual variability in the magnitude of the puerulus recruitment, but the time series of 8 years data used was not suitable for determining low frequency cycles.

Many are the reasons that could cause this growth pattern in the spiny lobster. As growth also depends on biomass via food competition (Pitcher and Hart 1982), an apparent dependence of growth on population density is common in studies of population dynamics.
However, the results here presented, based on the physiological concept underlying the von Bertalanffy growth function (Beverton and Holt 1957), density-dependence growth is revealed on the asymptotic length (or asymptotic weight) behavior, but not on the growth rate at which this size is approached. Although spiny lobsters are communal in nature, at very high densities, their growth can be depressed (Pollock 1991, Briones-Fourzan and LozanoAlvarez 2003), suggesting a density-dependent regulation of growth rate.

The evidence of decadal cycles in the growth coefficient of Caribbean spiny lobster perhaps has their origins in decadal environment variations. If we review the environmental conditions in Cuban waters, located in the North Atlantic sector, they must have an influence of three interconnected phenomena (Hurrell et al. 
2001, Marshall et al. 2001). The interannual climatic variability is determined by the easterly trade winds and has the influence of the prevailing ocean-atmosphere interaction in the northern sector of tropical Atlantic, where long-term time SST series contains low-frequency cycles in the scale of 10 to 20 years (Carton et al. 1996, Xie and Carton 2004).

Temperature is a decisive factor for growth (Fry 1971), because it controls the rate of metabolism. Caribbean spiny lobster, as a tropical crustacean, do not have an specific molting season, even though it has been proved that the process goes on faster in summer than in winter (Munro 1974, Davis 1981, Hunt and Lyons 1986, Forcucci et al. 1994).

Present results agree with the range reported for the optimum temperature for growth and survival in palinurids (Chittleborough 1977 ) in the range of $25^{\circ}-28^{\circ} \mathrm{C}$, but temperatures higher than this maximum are detrimental for lobster growth.

It seems that the optimal "window" for a successful growth rate in $P$. argus in Cuban waters according to temperature is around the $28^{\circ} \mathrm{C}$, but it will be necessary to explore other abiotic (like photoperiod, oxygen and salinity) and biotic (food availability and food quality) factors that limit the growth of organism (Fry 1971, Pitcher and Hart 1982). An additional motive of further investigation will be long-term field studies of these factors and their relation with juvenile stage abundance in nursery areas, where the changes could be more dramatic.

The traditional practice of predictive models used for fish resources is to consider population parameters such as growth, natural mortality, and recruitment as averages (stationary models). To take in consideration these results should be the basis for further advances in the understanding and prediction of Cuban lobster fishery dynamics and the role that could be played from now on in suitable management policies depending on the kind of variation observed.

\section{ACKNOWLEDGMENTS}

The present study is part of a Ph. D. thesis of the first author developed at Centro de Investigaciones Biológicas del Noroeste (CIBNOR) and granted by Consejo Nacional de Ciencia y Técnica of Mexico, CONACYT (Scholarship No 182843). Our thanks extend to the technical staff of our own institutions and to the Ministerio de la Industria Pesquera, M.I.P. of Cuba for the financial support. We gratefully acknowledge Akim Abel González (C.I.P., Cuba), Silvia Salas (CINVESTAV, Mexico) and the anonymous reviewers, for their valuable comments on the manuscript.

\section{RESUMEN}

Los parámetros de crecimiento anuales para la langosta espinosa del Caribe (Panulirus argus) en aguas cubanas se estimaron para una serie de 40 años de datos de composición por longitud, a través de los métodos indirectos basados en la talla ELEFAN y el nuevo SLCA. Las composiciones por talla de alrededor de 800000 langostas (con un ámbito de longitud de cefalotórax entre 14 y 199 $\mathrm{mm}$ ) fueron obtenidas en muestreos aleatorios, realizados en arrecifes artificiales (arte de pesca muy común en esta pesquería cubana), a través del programa de monitoreo de campo establecido para esta especie desde 1963 en 14 localidades del Golfo de Batabanó, plataforma suroccidental de Cuba. El método ELEFAN mostró problemas para convergir en una combinación óptima del coeficiente de crecimiento $(K)$ y el largo asintótico $\left(L_{\infty}\right)$ de la ecuación de von Bertalanffy, mientras que el método nuevo SLCA proporcionó valores de $K$ entre 0.20 y $0.27 \mathrm{año}^{-1}$ y de $L_{\infty}$ entre 177 y $190 \mathrm{~mm}$ de longitud de cefalotórax, todos dentro del ámbito reportado en la literatura. Las anomalías estandarizadas de ambos parámetros mostraron la existencia de ciclos a lo largo de la serie de tiempo analizada. El análisis espectral demostró una variabilidad decadal en los parámetros de crecimiento, con ciclos significativos de 16 y 20 años para $K$ y de 16 años para $L_{\infty}$. La incidencia de algunos factores, que modulan el crecimiento en este valioso crustáceo, como la biomasa y la temperatura fue explorada usando un modelo no-lineal de regresión múltiple. Los resultados indicaron que ambos factores combinados explican el $33 \%$ y el $69 \%$ de la variabilidad de la $K$ y del $L_{\infty}$ respectivamente. El coeficiente de crecimiento alcanzó 
su máximo con temperaturas medias anuales de superficie del mar de $28.1^{\circ} \mathrm{C}$ y el mayor valor de $L_{\infty}$ se alcanza con niveles en la biomasa media anual de $23000 \mathrm{t}$. La consideración de estos resultados debe ser la base para estudios posteriores en el conocimiento y predicción de la dinámica de la población de langosta en Cuba.

Palabras clave: Parámetros de crecimiento, variabilidad por década, Panulirus argus, Cuba.

\section{REFERENCES}

Acosta, A., T.R. Matthews \& M.J. Butler, IV. 1997. Temporal patterns and transport processes in recruitment of spiny lobster (Panulirus argus) postlarvae to south Florida. Mar. Biol. 129 (1): 79-85.

Arce, A.M. \& M.E. de León. 2001. Biology, p. 17-25. In P. Medley \& S. Venema (Eds.). Report on the FAO/ DANIDA/ CFRAMP/WECAFC regional workshops on the assessment of the Caribbean spiny lobster (Panulirus argus). FAO Fish. Rep. 619.

Arce, A.M. 1990. Estimación del crecimiento de langosta Panulirus argus (Latreille) con metodologías convencionales y a través de funciones de singularidad. Tesis de Maestria en Ciencias. Centro de Investigaciones de Estudios Avanzados (CINVESTAV)-Unidad Mérida. $94 \mathrm{p}$.

Arce, A.M., J.C. Seijo \& S. Salas. 1991. Cálculo del crecimiento de la langosta espinosa Panulirus argus Latreille, mediante funciones de singularidad. Rev. Invest. Mar 12: 184-192.

Báez, M., E. Díaz, R. Brito \& R. Cruz. 1991. Edad y crecimiento de la langosta en la plataforma suroccidental de Cuba. Rev. Invest. Mar. 12: 193-201.

Baisre, J.A. \& R. Cruz, 1994. The Cuban spiny lobster fishery. p. 119-132 In Phillips, B. F., J.,S. Cobb \& J. Kittaka. (Eds.). Spiny Lobster Management. London, Blackwell Sci. Oxford, Fishing New Books.

Beverton, R.J.H. \& S.J. Holt. 1957. On the dynamics of exploited fish populations. Fish. Invest. Ser. II Vol. $19.533 \mathrm{p}$

Breiman, L. \& J.H. Friedman. 1985. Estimating optimal transformation for multiple regression and correlation. J. Am. Stat. Ass. 80(391): 580-619.

Briones-Fourzán, P. \& E. Lozano-Alvarez. 2003. Factors affecting growth of the spiny lobsters Panulirus gracilis and Panulirus inflatus in Guerrero, Mexico. Rev. Biol. Trop. 51: 165-174.
Buesa, R. 1972. La langosta espinosa Panulirus argus: su pesca y biología en aguas cubanas. INP/CIP, Cuba. Reun. Balance de Trab. 3(1): 29-78.

Caddy, J.F. 1977. Approaches to a simplified yield-perrecruit model for Crustacea, with particular reference to the American lobster Homarus americanus. Fish. Mar. Serv. Rep. 1445, 14 p.

Carton, J.A., X.H. Cao, B.S. Giese \& D.A. da Silva. 1996. Decadal and interannual SST variability in the tropical Atlantic Ocean. J. Phys. Oceanogr. 26: 1162-1175.

Chittleborough, R.G., 1977. Environmental factors affecting growth and survival of juvenile Western rock lobster. Aust. J. Mar. Freshw. Res. 26: 177-196.

Clark, W.G., S.R. Hare, A.M. Parma, P.J. Sullivan \& R.J. Trumble. 1999. Decadal changes in halibut growth and recruitment. Can. J. Fish. Aquat. Sci. 56: $242-252$.

Cruz, R. 2002. Manual de métodos de muestreo para la evaluación de poblaciones de langosta espinosa. FAO Fish. Tech. Pap. 399, 43 p.

Cruz, R., M.E. de León, E. Díaz, R. Brito \& R. Puga. 1991. Reclutamiento de puerulus de langosta (Panulirus argus) a la plataforma cubana. Rev. Invest. Mar. 12: 66-75.

Cruz, R., R. Coyula \& A.T. Ramírez. 1981. Crecimiento y mortalidad de la langosta espinosa (Panulirus argus) en la plataforma suroccidental de Cuba: Rev. Cub. Inv. Pesq. 6(4): 89-119.

Cury, P., C. Roy, R. Mendelssohn, A. Bakun, D.M. Husby \& R.H. Parrish. 1985. Moderate is better: exploring nonlinear climatic effect on Californian anchovy (Engraulis mordax). Can. J. Mar. Aquat. Sci. 127: 417-424.

de León, M.E. de, R. Cruz \& R. Puga. 1995. Actualización de la edad y el crecimiento de la langosta espinosa Panulirus argus. Rev. Cub. Inv. Pesq. 19(2): 3-8.

de León, M.E. de, R. Puga \& R. Cruz. 1993. Estimación de los parámetros de crecimiento de Panulirus argus en el Golfo de Batabanó, Cuba. Rev. Cub. Inv. Pesq. 18(1): 9-12.

Forcucci, D., M.J. Butler IV \& J.H. Hunt. 1994. Population dynamics of juvenile Caribbean spiny lobster, Panulirus argus, in Florida Bay, Florida. Bull. Mar. Sci. 54: 805-818.

Fry, F.E.J. 1971. The effect of environmental factors on the physiology of fish, pp.1-98 In: Hoar, W.S. \& D.J. Randall (eds.), Fish Physiology Vol. 6. Academic, New York. 
Gayanilo, F.C., P. Sparre \& D. Pauly, 1996. The FAOICLARM Stock Assessment Tools (FISAT). FAO Computerized Information Series (Fisheries) No. 8.

González-Cano, J.M. 1991. Migration and refuge in the assessment and management of the spiny lobster Panulirus argus in the Mexican Caribbean. Ph.D. Thesis, Imperial College, London. 448 p.

Gulland, J.A. \& A.A. Rosenberg. 1992. Examen de los métodos que se basan en la talla para evaluar las poblaciones de peces. FAO Fish. Tech. Pap. 323: 113 p.

Hunt, J.H. \& W.G. Lyons. 1986. Factors affecting growth and maturation of spiny lobsters, Panulirus argus, in the Florida Keys. Can. J. Fish. Aquat. Sci. 43: 2243-2247.

Hurrell, J.W., Hoerling, M.P., C.K. Folland. 2001. Climatic variability over the North Atlantic, p. 143-151. In Pearce, R. Meteorology at the Millennium. Academic London.

Ivo, C.T.C. \& J.A. Pereira. 1996. Crescimento e idade das lagostas Panulirus argus (Latreille) e Panulirus laevicauda (Latreille), no norte e nordeste do Brasil. Arq. Cien. Mar. 30: 33-39.

Jensen, A.L. 1997. Origin of the relation between K and $\mathrm{L}_{\text {inf }}$ and synthesis of relations among life history parameters. Can. J. Fish. Aquat. Sci. 54: 987-989.

Knight, W. 1968. Asymptotic growth: An example of nonsense disguised as mathematics. J. Fish. Res. Board Can. 25: 1303-1307.

Marshall J., Y. Kushnir, D. Battisti, P. Chang, A. Czaja, R. Dickson, J. Hurrel, M. McCartney, R. Saravanan \& M. Visbeck. 2001. North Atlantic climate variability; Phenomena, impacts and mechanisms. Int. J. Climatol. 21: 1863-1898.

Munro, J.L. 1974. The biology, ecology, exploitation, and management of Caribbean reef fishes. Part V. 1. The biology, ecology and bionomics of Caribbean reef fishes: Crustaceans (spiny lobsters and crabs). Univ. West Indies Zool. Dep. Res. Rep. 3: 1-57. Davis, G. E. 1981. Effect of injuries on spiny lobster, Panulirus argus, and implications for fishery management. Fish. Bull. 78: 979-984.

Páez, J. \& N. Revilla, 1991. Relación entre la captura por unidad de área de la langosta (Panulirus argus) y los diferentes biotopos en el Golfo de Batabanó, Cuba. Rev. Invest. Mar. 12: 269-279.

Pauly, D. \& F. Arreguín-Sánchez. 1995. Improving Shepherd's length composition analysis (SLCA)
Method for growth parameter estimations. NAGA ICLARM Q. 18(4), 31-33.

Pauly, D. \& N. David. 1981. ELEFAN I. a BASIC program for the objective extraction of growth parameters from length frequency data. Meeresforsch. 28(4): 205-211.

Pauly, D. \& G.R. Munro. 1984. Once more in the comparison of growth in fish and invertebrates. Fishbyte 2(1): 21 .

Pitcher, T.J. \& P.J.B. Hart. 1982. Fishery Ecology. The AVI, Westport, Connecticut. 414 p.

Pollock, D.E. 1991. Spiny lobsters at Tristan da Cunha, South Atlantic: inter-island variations in growth and population structure. S. Afr. J. Mar. Sci. 10: 1-12.

Puga, R. \& M.E. de León,. 2003. La pesquería de la langosta en Cuba. In: Report of the Second Workshop on the Management of Caribbean Spiny Lobster Fisheries in the WECAF Area. FAO Fish. Rep. 715: 85-91.

Puga, R., S. Hernández-Vázquez, J. López-Martínez \& M.E. de León. 2005. Bioeconomic modelling and risk assessment of the Cuban fishery for spiny lobster Panulirus argus. Fish. Res. 75(1-3): 149-163.

Reynolds, R.W., T.M. Rayner, D.C. Stokes \& W. Wang. 2002. An improved in situ and satellite SST analysis for climate. J. Climate, 16: 1609-1625.

Roff, D.A. 1980. A motion to retire the von Bertalanffy function. Can. J. of Fish. Aquat. Sci. 37: 127-129.

Shepherd, J.G., 1987. A weakly parametric method for estimating growth parameters from length composition data, pp.113-119. In: D. Pauly \& G.R. Morgan. (eds.). Length-based methods in fisheries research. ICLARM Conference Proceedings, 13: 468 p.

Tavares, M. 2002. Lobsters. (pp. 294-325) In K.E. Carpenter (ed.). The living marine resources of the Western Central Atlantic. Vol. 1, FAO Species Identification guide for fishery purposes and American Society of Ichthyologists and Herpetologists Spec. Publ. No. 5, FAO Roma; $600 \mathrm{p}$.

Xie, S.P. \& J.A Carton. 2004. Tropical Atlantic variability. Patterns, mechanisms and impacts (pp 121-142) In Wang, C., S.P. Xie \& J.A. Carton. Earth climate: The ocean-atmosphere interaction. Geophysical Monograph, 147. AGU, Washington DC.

Zetina-Moguel, C.E. \& G.V. Ríos-Lara. 1999. Modelos de crecimiento de langosta (Panulirus argus) y un método para calcular la edad. Ciencia Pesquera 14: 57-61. 